ISSN 0258-7122 (Print), 2408-8293 (Online)

Bangladesh J. Agril. Res. 41(4): 667-673, December 2016

\title{
IPNS BASED FERTILIZER MANAGEMENT FOR RICE IN COASTAL ZONE OF BANGLADESH
}

\author{
M. N. ISLAM ${ }^{1}$, M. I. U. SARKAR ${ }^{2}$, M. H. ALI ${ }^{3}$ \\ A. ISLAM ${ }^{4}$ AND P. K. SAHA ${ }^{5}$
}

\begin{abstract}
A series of field experiments were conducted at farmers' fields under Ganges Tidal Floodplain (AEZ-13) during 2012-2014 to identify suitable fertilizer management practices for maximizing rice yield. The treatments were: $T_{1}=A E Z$ basis BRRI recommended fertilizer dose (BRRI dose), $\mathrm{T}_{2}=$ Rice Straw (RS)/Cowdung (CD) + IPNS (Integrated Plant Nutrition System) basis fertilizer management (RS/CD+IPNS) and $\mathrm{T}_{3}=$ Farmers' Practice (FP). BRRI dhan $27(\mathrm{~T}$. Aus), BRRI dhan49 and BRRI dhan54 (T. Aman) and BRRI dhan29 and BRRI dhan47 (Boro) were used as test varieties of rice. All fertilizers except urea were applied at final land preparation. In T. Aus and T. Aman seasons, urea was applied in two equal splits as FP. In Boro season, urea was added in three equal splits as FP. Urea Super Granule (USG) was applied at 12-15 DAT for $\mathrm{T}_{1}$ and $\mathrm{T}_{2}$ treatments. Treatment RS + IPNS gave 19-27\% higher grain yield over FP and it saved full dose of K and S and partial dose of P fertilizer. Treatment CD + IPNS gave a 10-16\% higher grain yield over FP and it saved full dose of P, K and S fertilizer in T. Aus and T. Aman seasons. On the other hand, BRRI recommended fertilizer dose gave $7-15 \%$ higher grain yield over FP.
\end{abstract}

Keywords: AEZ-13, Chemical Fertilizer, Cowdung, Rice Straw and USG.

\section{Introduction}

Total area of Bangladesh is $147,570 \mathrm{~km}^{2}$ of which the coastal area covers about $20 \%$ and over thirty percent in respect of net cultivable area. The cultivable areas in coastal districts are affected with varying degrees of soil salinity. Both level and area of salinity have increased with time. The saline area is now 1.06 mha which was 0.83 mha in 1973. The constraints of crop production include soil and water salinity, poor soil fertility, heavy soil consistency and low osmotic potential. Salinity increases in dry months showing a peak in March-April and decreases in wet months with the minimum in July-August. The farmers of the coastal region usually cultivate traditional varieties and harvest about 2.0-2.5t/ha/year. The present need is to achieve higher crop yield than the present yield levels from our limited land resources on a sustainable basis. A crop production system with high yield targets can not be sustainable unless nutrient inputs to soil are at least balanced against nutrient

\footnotetext{
${ }^{1 \& 2}$ Scientific Officer, Soil Science Division, ${ }^{3}$ Scientific Officer, Irrigation and Water Management Division, ${ }^{4}$ Principal Scientific Officer, Soil Science Division, ${ }^{5}$ Chief Scientific Officer (Ex.), Soil Science Division, Bangladesh Rice Research Institute (BRRI), Gazipur, Bangladesh.
} 
removal by crops (Bhaiyan et al., 1994). Proper soil fertility management, therefore, is one of the prime importances in an endeavor to increase crop productivity. Organic matter content in cultivated soils of Bangladesh is generally low and is in declining trend in high and medium high land areas. Now, it is required to develop an integrated inorganic-organic fertilization program for improved soil health and higher crop yield. Moreover, the use of organic manure reduces the need of chemical fertilizer. Keeping the above points in view, the present study was undertaken to find out efficient nutrient management practices for maximizing rice yield in Ganges Tidal Floodplain.

\section{Materials and Method}

Experimental sites and seasons: On-farm experiments were conducted in continuous rice-rice cropping systems for six consecutive seasons (T. Aus 2012, T. Aman 2012, Boro 2012-13, T. Aus 2013, T. Aman 2013 and Boro 2013-14). Experiments were set up in Barisal region (coastal area) at 15 sites over Bakergonj, Barisal sadar and Ujirpur Upazila under Barisal district, Nalchity and Jhalkathi sadar Upazila under Jhalkathi district, Dumki and Patuakhali sadar Upazila under Patuakhali district and Amtoli Upazila under Barguna district. Those were selected to represent the most common land and soil types, cropping systems and farm management practices in coastal area of Barisal region. All the sites belong to AEZ 13 (Ganges Tidal Floodplain). Texturally the soils were silty clay to clay loam. Some basic soil properties are shown in the Table 1. Transplanted rice was grown on puddled soil with partial irrigation in three seasons, February-March to June-July, June-July to November-December and November-December to March-April, which is known as the Aus, Aman and Boro season, respectively.

Table 1. Initial soil properties (0-15 cm depth) of farmers' fields of different Upazilas in the coastal region.

\begin{tabular}{l|c|c|c|c|c|c|c}
\hline \multirow{2}{*}{ Locations } & \multirow{2}{*}{$\mathrm{pH}$} & $\mathrm{OM}$ & Total N & Av. K & Av. P & Av. S & Av. Zn \\
\cline { 2 - 8 } & & \multicolumn{2}{|c}{$\%$} & $\mathrm{cmol} \mathrm{kg}^{-1}$ & \multicolumn{3}{c}{$\mathrm{mg} \mathrm{kg}^{-1}$} \\
\hline Ujirpur & $6.0-7.2$ & $1.23-2.10$ & $0.13-0.20$ & $0.20-0.24$ & $7-16$ & $19-28$ & $0.8-1.6$ \\
\hline Amtoli & $6.3-7.5$ & $1.20-2.30$ & $0.10-0.12$ & $0.20-0.27$ & $4-14$ & $35-44$ & $0.7-1.8$ \\
\hline Jhalkathi & $5.9-6.8$ & $1.30-1.70$ & $0.13-0.15$ & $0.16-0.22$ & $8-14$ & $22-36$ & $1.3-2.0$ \\
sadar & & & & & & & \\
\hline Nalchiti & $6.4-7.0$ & $1.42-2.16$ & $0.09-0.15$ & $0.18-0.23$ & $10-18$ & $26-37$ & $1.0-2.3$ \\
\hline Bakerganj & $6.2-7.0$ & $1.72-2.19$ & $0.09-0.11$ & $0.21-0.26$ & $12-19$ & $24-40$ & $1.8-2.2$ \\
\hline Dumki & $6.5-7.8$ & $1.50-1.70$ & $0.09-0.12$ & $0.23-0.25$ & $9-14$ & $20-34$ & $0.8-2.4$ \\
\hline Barisal sadar & $6.2-6.7$ & $1.13-1.89$ & $0.10-0.19$ & $0.17-0.23$ & $8-17$ & $23-35$ & $0.6-1.5$ \\
\hline
\end{tabular}


Experimental design and treatments: The experiments were established in farmers' fields in a randomized complete block design with three treatments. The experimental area had similar pest management and uniform soil type, and each field was considered a replication. The number of replications varied with sites and seasons and totaled six at three sites in T. Aus 2012, nine at four sites in T. Aman 2012, four at two sites in Boro 2012-13, six at three sites in T. Aus 2013, seven at four sites in T. Aman 2013, five at three sites in Boro 2013-14. Farmers' fields were selected from marginal, small, and medium category farmers through group discussion with the farming communities of selected villages to ensure that fertilizer management practices of selected farmers are representative of the respective village. Layout was done carefully maintaining unit plot size of $8 \mathrm{~m} \times$ $6 \mathrm{~m}$ for each treatment. Ridges (bunds) were given for protecting unexpected irrigation water entrance into the plots or avoid contamination of water. Three seedlings per hill were transplanted at $20 \mathrm{~cm} \times 20 \mathrm{~cm}$ spacing. The tested cultivars were BRRI dhan27 (T. Aus), BRRI dhan49 or BRRI dhan54 (T. Aman) and BRRI dhan 29 or BRRI dhan47 (Boro). Treatments consisted of options for managing fertilizers in rice. Following treatment combinations were tested with dispersed replications: $\mathrm{T}_{1}=\mathrm{BRRI}$ recommended dose $(\mathrm{BRRI}$ dose $), \mathrm{T}_{2}=$ Rice straw (RS)/Cow dung (CD) + IPNS based chemical fertilizer (IPNS) and $\mathrm{T}_{3}=$ Farmers' practice (FP).

Applied N, P, K, S and Zn for $\mathrm{T}_{1}$ were 50-11-15-3-1, 50-15-17-4-2 and 75-3030-6-3 kg ha ${ }^{-1}$ for T. Aus, T. Aman and Boro season, respectively while 37-1510-0-0, 42-25-0-0-0 and 114-25-41-7-6 kg ha-1 in $\mathrm{T}_{3}$ for T. Aus, T. Aman and Boro season, respectively. Treatment details for $\mathrm{T}_{2}$ are given in Table 2. The sources of nutrients N, P, K, S and Zn were urea, TSP, MoP, Gypsum and Zinc sulphate, respectively. All TSP, MoP, gypsum, zinc sulphate and rice straw/cowdung were applied at final land preparation. Chemical compositions of rice straw and cowdung are presented in Table 3. In T. Aus and T. Aman season, urea was applied in two splits (67\% at 15 DAT and rest 33\% at 5-7 days before PI stage) in the treatment of farmers' practice $\left(\mathrm{T}_{3}\right)$. In Boro season, urea was applied in three splits (34\% at 15 DAT, $44 \%$ at 35 DAT and rest $22 \%$ at 5-7 days before PI stage) in the treatment of farmers' practice $\left(\mathrm{T}_{3}\right)$. In the treatments of $\mathrm{T}_{1} \& \mathrm{~T}_{2}$, one piece of urea super granule (USG) was placed in the middle of four hills at a depth of 7.5-10 cm. The weight of one piece of USG was $1.8 \mathrm{~g}, 1.8$ $\mathrm{g}$ and $2.7 \mathrm{~g}$ for $\mathrm{T}$. Aus, T. Aman and Boro rice, respectively. All crop management operations (seedling raising, land preparation, crop establishment, irrigation, weed control, insect and disease control) were done across the sites and treatments. Monitoring was done through frequent field visit and keeping close contact with respective farmers during the crop growing period. 
Table 2. Treatment details for RS/CD + IPNS* $\left(\mathrm{T}_{2}\right)$

\begin{tabular}{l|c|c|c|c|c|c}
\hline \multirow{2}{*}{ Season/year } & \multicolumn{5}{c|}{$\begin{array}{c}\text { Nutrient applied from chemical fertilizer } \\
\left(\mathrm{kg} \mathrm{ha}^{-1}\right)\end{array}$} & \multirow{2}{*}{$\begin{array}{c}\text { Organic material } \\
\left.\text { applied ( } \mathrm{t} \mathrm{ha}^{-1}\right)\end{array}$} \\
\cline { 2 - 6 } & $\mathrm{N} * *$ & $\mathrm{P}$ & $\mathrm{K}$ & $\mathrm{S}$ & $\mathrm{Zn}$ & \\
\hline T. Aus 2012 & 50 & 7 & 0 & 0 & 0.6 & $\mathrm{RS}=4.5$ (sundry) \\
T. Aman 2012 & 50 & 11 & 0 & 0 & 1.8 & $\mathrm{RS}=4.5$ (sundry) \\
Boro 2012-13 & 75 & 25 & 0 & 1.5 & 2.5 & $\mathrm{RS}=4.5$ (sundry) \\
\hline T. Aus 2013 & 50 & 0 & 0 & 0 & 0.7 & $\mathrm{CD}=3.0$ (oven dry) \\
T. Aman 2013 & 50 & 0 & 0 & 0 & 1.7 & $\mathrm{CD}=3.0$ (oven dry) \\
Boro 2013-14 & 75 & 6 & 0 & 0 & 2.7 & $\mathrm{CD}=3.0$ (oven dry) \\
\hline
\end{tabular}

*IPNS was followed in all elements (P, K, S and Zn) except $\mathrm{N}$ due to USG application

$* * \mathrm{~T}_{1} \& \mathrm{~T}_{2}-\mathrm{N}$ was applied as $\mathrm{USG}$ and $\mathrm{T}_{3}$ - as $\mathrm{PU}$

Table 3. Chemical composition of rice straw and cowdung

\begin{tabular}{lccccc}
\hline Organic matter & $\mathrm{N}(\%)$ & $\mathrm{P}(\%)$ & $\mathrm{K}(\%)$ & $\mathrm{S}(\%)$ & $\mathrm{Zn}(\%)$ \\
\hline Rice straw & 0.5 & 0.08 & 1.6 & 0.09 & 0.01 \\
Cowdung & 1.2 & 0.8 & 1.3 & 0.13 & 0.01 \\
\hline
\end{tabular}

Source: Saha et al. (2004)

Soil and plant sampling and analysis: Initial soil samples were collected from each farmer's field at $0-15 \mathrm{~cm}$ depth from 9 spots and were mixed thoroughly to make a composite sample. Then the sample was air-dried and sieved to pass through a 2-mm sieve. Soil samples were analyzed for determination of $\mathrm{pH}$, total $\mathrm{N}$, organic matter, available $\mathrm{P}$, exchangeable $\mathrm{K}$, available $\mathrm{S}$ and available $\mathrm{Zn}$ contents (Islam et al., 2014 and Saha et al., 2016).

Grain yield was recorded from the central $5 \mathrm{~m}^{2}$ harvest area in each plot at maturity and reported on 14\% moisture basis. At maturity, 16 hills (four hills from each of the four sides of the grain harvest area) were collected at ground level and fresh straw weight was determined after separating the grains. Grain and straw were dried at $70^{\circ} \mathrm{C}$ to constant weight and dry weights were recorded. The ratio of fresh and oven-dry weights of straw for 16-hill samples was then used to determine straw yields on an oven-dry basis from fresh straw weights (Islam \& Muttaleb, 2016).

Data analysis: Analysis of variance (ANOVA) was performed on yield to determine the effects of different treatments using the IRRISTAT software 
version 4.1 (IRRI, 1998). Least significant difference (LSD) at the 5\% level of probability was used to evaluate the differences among treatment means.

\section{Results and Discussion}

T. Aus 2012: BRRI dose and IPNS produced significantly higher grain and straw yields over FP (Table 4). The IPNS treatment gave superior rice yield to BRRI dose. The highest grain yield of $4.38 \mathrm{t} \mathrm{ha}^{-1}$ was obtained with IPNS, which was $26.59 \%$ higher than that obtained with FP. The BRRI dose produced $3.99 \mathrm{t} \mathrm{ha}^{-1}$ grain yield showing a $15.32 \%$ higher yield over FP. Similar trend was also observed in case of straw yield (Table 4).

T. Aman 2012: IPNS produced significantly higher yield compared to BRRI dose and FP. The IPNS treatment demonstrated the highest grain yield of $4.01 \mathrm{t}$ $\mathrm{ha}^{-1}$ which was followed by $3.66 \mathrm{t} \mathrm{ha}^{-1}$ yield due to BRRI dose (Table 4). The yield benefits obtained with these two treatments over FP were $19 \%$ and $8.61 \%$, respectively. Similarly, straw yield was significantly higher with IPNS followed by BRRI dose and FP (Table 4). However, BRRI dose gave statistically similar straw yield with FP.

Boro 2012-13: In Boro season, the highest grain yield $\left(7.52 \mathrm{t} \mathrm{ha}^{-1}\right)$ was obtained with IPNS where RS at $4.5 \mathrm{t} \mathrm{ha}^{-1}$ (sun dry) + IPNS based fertilizers were applied (Table 4). This result is in agreement with the data obtained from other experiments (Saha et al., 2009). Grain yield with FP was significantly lower $\left(6.28 \mathrm{t} \mathrm{ha}^{-1}\right)$ than that of BRRI dose and IPNS. IPNS gave $19.75 \%$ higher grain yield than FP. The BRRI dose produced $6.90 \mathrm{t} \mathrm{ha}^{-1}$ grain yield which was $9.87 \%$ higher than that of FP. The straw yield of Boro rice was significantly higher with IPNS and BRRI dose compared to FP (Table 4).

Table 4. Grain and straw yields $\left(\mathrm{t} \mathrm{ha}^{-1}\right)$ of T. Aus, T. Aman and Boro rice as influenced by different fertilizer management practices in coastal area

\begin{tabular}{l|c|c|c|c|c|c}
\hline \multirow{2}{*}{ Treatments } & \multicolumn{2}{c|}{ T. Aus, 2012 } & \multicolumn{2}{c|}{ T. Aman, 2012 } & \multicolumn{2}{c}{ Boro, 2012-13 } \\
\cline { 2 - 8 } & $\begin{array}{c}\text { Grain } \\
\text { Yield }\end{array}$ & $\begin{array}{c}\text { Straw } \\
\text { yield }\end{array}$ & $\begin{array}{c}\text { Grain } \\
\text { Yield }\end{array}$ & $\begin{array}{c}\text { Straw } \\
\text { yield }\end{array}$ & $\begin{array}{c}\text { Grain } \\
\text { Yield }\end{array}$ & $\begin{array}{c}\text { Straw } \\
\text { yield }\end{array}$ \\
\hline BRRI dose & 3.99 & 3.84 & 3.66 & 3.32 & 6.90 & 5.62 \\
IPNS & 4.38 & 4.41 & 4.01 & 4.05 & 7.52 & 5.58 \\
FP & 3.46 & 3.32 & 3.37 & 3.09 & 6.28 & 4.78 \\
\hline LSD $_{0.05}$ & 0.40 & 0.34 & 0.14 & 0.46 & 0.61 & 0.69 \\
CV $(\%)$ & 7.90 & 6.80 & 3.80 & 13.10 & 5.10 & 7.50 \\
\hline
\end{tabular}

T. Aus 2013: It appears from Table 5 that BRRI dose and IPNS produced significantly higher grain and straw yields over FP. The maximum grain yield of $4.04 \mathrm{t} \mathrm{ha}^{-1}$ was obtained with IPNS, which was $15.76 \%$ higher than that of 
FP. The BRRI dose produced $3.87 \mathrm{t} \mathrm{ha}^{-1}$ grain yield exhibiting $10.89 \%$ higher than FP. The straw yield followed the similar trend: IPNS > BRRI dose > FP. (Table 5).

T. Aman 2013: Nutrient management options significantly affected grain and straw yields in T. Aman season (Table 5). IPNS based nutrient management without any other change in crop management practices significantly increased yield as compared to the FP (3.99 vs. $\left.3.62 \mathrm{t} \mathrm{ha}^{-1}\right)$. The findings support the results obtained by Saha and Miah (2009). The highest grain yield of $3.99 \mathrm{t} \mathrm{ha}^{-1}$ was obtained with the treatment IPNS which was $10.22 \%$ higher than FP while BRRI dose produced $3.86 \mathrm{t} \mathrm{ha}^{-1}$ grain yield (i.e. $6.63 \%$ higher than FP). In case of straw yield, IPNS treatment only produced significantly higher yield over FP (Table 5).

Boro 2013-14: The grain yield of Boro rice increased significantly with BRRI dose and IPNS in comparison with FP. The highest grain yield of $6.91 \mathrm{t} \mathrm{ha}^{-1}$ was obtained with IPNS which was $10.91 \%$ higher than FP. The BRRI dose produced $6.70 \mathrm{t} \mathrm{ha}^{-1}$ grain yield (i.e. 7.54\% higher than FP) (Table 5). Similar trend was also observed in case of straw yield (Table 5).

Table 5. Grain and straw yields $\left(\mathrm{t} \mathrm{ha}^{-1}\right)$ of T. Aus, T. Aman and Boro rice as influenced by different fertilizer management practices in coastal area

\begin{tabular}{l|c|c|c|c|c|c}
\hline \multirow{2}{*}{ Treatments } & \multicolumn{2}{|c|}{ T. Aus, 2013 } & \multicolumn{2}{c|}{ T. Aman, 2013 } & \multicolumn{2}{c}{ Boro, 2013-14 } \\
\cline { 2 - 7 } & $\begin{array}{c}\text { Grain } \\
\text { Yield }\end{array}$ & $\begin{array}{c}\text { Straw } \\
\text { yield }\end{array}$ & $\begin{array}{c}\text { Grain } \\
\text { Yield }\end{array}$ & $\begin{array}{r}\text { Straw } \\
\text { yield }\end{array}$ & $\begin{array}{c}\text { Grain } \\
\text { Yield }\end{array}$ & $\begin{array}{c}\text { Straw } \\
\text { yield }\end{array}$ \\
\hline BRRI dose & 3.87 & 7.21 & 3.86 & 4.50 & 6.70 & 7.21 \\
IPNS & 4.04 & 7.43 & 3.99 & 4.32 & 6.91 & 7.50 \\
FP & 3.49 & 5.83 & 3.62 & 4.02 & 6.23 & 6.66 \\
\hline LSD $_{0.05}$ & 0.28 & 0.73 & 0.29 & 0.38 & 0.32 & 0.34 \\
CV $(\%)$ & 5.70 & 8.40 & 6.40 & 7.60 & 3.30 & 3.20 \\
\hline
\end{tabular}

Application of organic material (RS/CD) with IPNS basis chemical fertilizer was found to be a better option to obtain a maximum rice yield with a good saving of chemical fertilizer. Rice straw incorporation @ $4.5 \mathrm{t} \mathrm{ha}^{-1}$ saved $50 \mathrm{~kg}$ urea, $18 \mathrm{~kg}$ TSP, $144 \mathrm{~kg} \mathrm{MoP}$ and $25 \mathrm{~kg}$ gypsum ha ${ }^{-1}$. Cowdung $3.0 \mathrm{t} \mathrm{ha}^{-1}$ substituted urea 78 $\mathrm{kg}$, TSP $120 \mathrm{~kg}$, MoP $78 \mathrm{~kg}$ and gypsum $25 \mathrm{~kg} \mathrm{ha}^{-1}$. Organic material might perform as mulches which would reduce the adverse effect of salinity on plant growth. So, IPNS based fertilizer management might play a vital role on rice yield and soil health in Ganges plain areas.

\section{Conclusion}

Application of rice straw/cowdung with IPNS basis chemical fertilizer performed the best to achieve higher rice yield and use of BRRI recommended fertilizer 
dose gave higher grain yield compared to farmers' practice (FP). Application of rice straw can fully substitute the use of potash and sulphur fertilizer and partially can save the other elements while cowdung can save full dose of phosphate, potash and sulphur fertilizer and partially can save other elements. Organic manure also helps improve soil health.

\section{Acknowledgement}

We are grateful to the authority of "Integrated Agricultural Productivity Project (IAPP)", funded by World Bank and Government of Bangladesh for providing financial support to this study.

\section{References}

Bhuiyan, N. I., A. L. Shah and G. M. Panaullah. 1991. Effect of NPK fertilization on the grain yield of transplanted rice and soil fertility - a long-term study. Bangladesh $J$. Soil Sci. 22(1\&2): 41-50.

IRRI (International Rice Research Institute). 1998. IRRISTAT for windows, Version 4.1, Biometrics unit, Int. Rice Res. Inst. Los Banos, Philippines.

Islam A. and A. Muttaleb. 2016. Effect of potassium fertilization on yield and potassium nutrition of Boro rice in a wetland ecosystem of Bangladesh. Arch. Agron. and Soil Sci. DOI: $10.1080 / 03650340.2016 .1157259$.

Islam, M. N., M. M. Rahman, M. J. A. Mian, M. H. Khan and R. Barua. 2014. Leaching losses of nitrogen, phosphorus and potassium from the sandy loam soil of Old Brahmaputra Floodplain (AEZ-9) under continuous standing water condition. Bangladesh J. Agric. Res. 39(3): 437-446.

Saha, P. K. and M. A. M. Miah. 2009. Efficiency of IPNS-based chemical fertilizer application in wetland rice. Bangladesh J. Agric. Res. 34(1): 5-13.

Saha, P. K., A. T. M. S. Hossain, U. A. Naher and M. A. Saleque. 2004. Nutrient composition of some manure and crop residues. Bangladesh J. Agric. Res. 29(1): 165-168.

Saha, P. K., M. A. M. Miah, A. T. M. S. Hossain, F. Rahman and M. A. Saleque. 2009. Contribution of rice straw to potassium supply in rice-fallow-rice cropping pattern. Bangladesh J. Agric. Res. 34(4): 633-643.

Saha, P. K., S. Islam, M. N. Islam, J. C. Biswas and M. M. Haque. 2016. Soil plant nutrient status under intensive rice-farming systems in unfavorable eco-systems of Bangladesh. Int. J. Chem. and Pharmac. 2(2): 1-13. 